\title{
Menthalactone, a New Analgesic from Mentha cordifolia Opiz. Leaves
}

\author{
Irene M. Villaseñor* and Arlyn C. Sanchez \\ Institute of Chemistry, University of the Philippines, Diliman, Quezon City 1101, \\ Philippines. Fax: (63-2)9205427. E-mail: irene.villasenor@up.edu.ph \\ * Author for correspondence and reprint requests \\ Z. Naturforsch. 64c, 809-812 (2009); received May 7/July 23, 2009 \\ Menthalactone, a new long-chain alkene with a bicyclic lactone moiety, was isolated as \\ an analgesic constituent from the leaves of Mentha cordifolia Opiz. At a dosage of $100 \mathrm{mg} /$ \\ $\mathrm{kg}$ mouse, it decreased the number of squirms induced by acetic acid by $67.3 \%$. Statistical \\ analysis using Kruskall Wallis one-way analysis of variance by ranks showed that menthalac- \\ tone is different from the solvent control at $\alpha=0.01$ and approximates the analgesic activity \\ of mefenamic acid at 0.001 level of significance.
}

Key words: Mentha cordifolia Opiz., Analgesic, Menthalactone

\section{Introduction}

Mentha cordifolia Opiz. (Lamiaceae), commonly known as mint, peppermint or marshmint, is cultivated throughout the Philippines and propagated by terminal cuttings. $M$. cordifolia is listed as one of the priority plants under the Department of Science and Technology (DOST), Philippine Council for Health Research and Development (PCHRD), National Integrated Research Program on Medicinal Plants (NIRPROMP). Its powdered dried leaves are presently being produced in tablet form, including pediatric tablets, and have been proven to be analgesic in clinical trial phases I, II, and III (Maramba et al., 1991). It is used against toothache, headache, muscle pain, dysmenorrhea, and in post-operative pain in secondary minor surgery (Maramba et al., 1993).

The mint family is characterized by its volatile oils. The leaves of $M$. cordifolia contain $0.8 \%$ volatile oil, consisting mainly of pulgenone, pitoeitone, and limonene (Tan, 1978), menthol, menthene, and menthenone (Quisumbing, 1978). Other constituents include cadinene, 1-carvomenthone, isomenthone, 4,8-epoxy-p-menthan-3-one, 2-isopropylcyclopentanone, 3,7-dimethyl-1,6-octadien-3-ol (linalool) (major component of oil), and $p$-menthan-2,5-diol. The present paper reports the bioassay-directed purification and structure elucidation of an analgesic constituent from M. cordifolia leaves. The analgesic activity was monitored using the acetic acid-induced writhing test.

\section{Results and Discussion}

The hexane (FB) and EtOAc (FD) extracts reduced the number of squirms induced by acetic acid by $81.4 \%(\alpha=0.05)$ and $71.0 \%(\alpha=0.15)$, respectively. Column chromatography of the hexane extract resulted in ten fractions (FB1-FB10) and the subsequent bioassay showed that fraction FB6, at a dosage of $0.25 \mathrm{mg} / \mathrm{g}$ mouse, is analgesic $(\alpha=0.03)$. The analgesic constituents isolated from fractions FB2 and FB10 were $\beta$-sitosterol and its glucoside, respectively (Villaseñor et al., 2002).

Fraction FB6F, resulted from normal phase liquid chromatography of FB6, at a dosage of $0.10 \mathrm{mg} / \mathrm{g}$ mouse, reduced the number of squirms induced by acetic acid by $60.6 \%(\alpha=0.01)$. Repeated and sequential chromatography of FB6F followed by recrystallization afforded white crystals labeled as FB6Fc. Although $\mathrm{FB} 6 \mathrm{Fc}$ is not completely soluble in either corn oil or $2 \%$ carboxymethylcellulose (CMC) in normal saline solution (NSS), results of the bioassay (Table I) showed that it possesses analgesic activity $(\alpha=$ 0.01 ) at a dosage of $0.10 \mathrm{mg} / \mathrm{g}$ mouse.

Isolate $\mathrm{FB} 6 \mathrm{Fc}$ is soluble in $30 \% \mathrm{MeOH} / \mathrm{CHCl}_{3}$ with an $\mathrm{Rf}$ value of 0.48 in $10 \% \mathrm{MeOH} / \mathrm{CHCl}_{3}$. It is detected with iodine crystals and turns into pink upon heating after spraying with vanillin-sulfuric acid but it is UV-inactive. Its ${ }^{13} \mathrm{C} N M R$ and DEPT spectra showed 23 carbon signals with one $-\mathrm{CH}_{3}$, fifteen $-\mathrm{CH}_{2}$, six $-\mathrm{CH}$ and one quaternary 
Table I. Analgesic activity of menthalactone using the acetic acid-induced writhing test.

\begin{tabular}{lccc}
\hline Test solution & $\begin{array}{c}\text { Dose } \\
\text { (mg/g mouse) }\end{array}$ & $\begin{array}{c}\text { No. of squirms } \\
\pm \text { S.D. }\end{array}$ & $\begin{array}{c}\text { Reduction in no. } \\
\text { of squirms (\%) }\end{array}$ \\
\hline HOAc & $0.01 \mathrm{ml}$ & $43.0 \pm 18.8$ & \\
HOAc + mefenamic acid & 0.007 & $11.6 \pm 10.1$ & 73.0 \\
HOAc + corn oil & $0.01 \mathrm{ml}$ & $48.0 \pm 10.1$ & \\
HOAc + menthalactone dissolved in corn oil & 0.1 & $17.5 \pm 13.3$ & 63.5 \\
HOAc + 2\% CMC in NSS & $0.2 \mathrm{ml}$ & $44.0 \pm 10.6$ & 67.3 \\
HOAc + menthalactone dissolved in 2\% CMC in NSS & 0.1 & $14.4 \pm 13.8$ & 6 \\
\hline
\end{tabular}

Positive control, HOAc + mefenamic acid; solvent controls, HOAc + corn oil and HOAc $+2 \%$ carboxymethylcellulose (CMC) in normal saline solution (NSS).

C signal. The FTIR spectrum showed the presence of a primary amine at 3332 and $3221 \mathrm{~cm}^{-1}$ and a C-N stretching vibration at $1278 \mathrm{~cm}^{-1}$. The ${ }^{13} \mathrm{C}$ NMR signals were therefore characteristic of an amine and three ether linkages from $\delta_{\mathrm{C}} 60.6$ to $\delta_{\mathrm{C}} 75.1, \delta_{\mathrm{H}} 3.28$ to $\delta_{\mathrm{H}} 3.86$ and a C-O stretching vibration at $1121 \mathrm{~cm}^{-1}$. A long-chain alkene was apparent from signals for the doubly bound carbon atoms at $\delta_{\mathrm{C}} 130.3, \delta_{\mathrm{C}} 129.5, \delta_{\mathrm{H}} 5.15$, and a $\mathrm{C}=\mathrm{C}$ stretching vibration at $1623 \mathrm{~cm}^{-1}$; the allylic carbon atoms at $\delta_{\mathrm{C}} 32.2, \delta_{\mathrm{C}} 32.0, \delta_{\mathrm{H}} 1.76$ and $\delta_{\mathrm{H}} 1.71$; and the aliphatic carbon atoms at $\delta_{\mathrm{C}} 29$ and $\delta_{\mathrm{H}} 1.01$ clusters. The signal at $\delta 175.5$ and a $\mathrm{C}=\mathrm{O}$ stretching vibration at $1756 \mathrm{~cm}^{-1}$ indicate the presence of an ester. The positive ion mode ESI-mass spectrum showed a molecular ion peak at $m / z, 380[\mathrm{M}+\mathrm{H}]^{+}$giving the molecular formula of $\mathrm{C}_{23} \mathrm{H}_{41} \mathrm{NO}_{3}$.

Cross peaks in the COSY spectrum between the geminal protons at $\delta_{\mathrm{H}} 3.55$ and 3.49, the geminal protons and $\delta_{\mathrm{H}} 3.86, \delta_{\mathrm{H}} 3.86$ and $\delta_{\mathrm{H}} 3.29$, and $\delta_{\mathrm{H}} 3.29$ and $\delta_{\mathrm{H}} 1.17$ gave fragment 1 . HMBC cross peaks between the geminal protons and $\delta_{\mathrm{C}} 51.2$ $\left({ }^{2} J\right)$ and $\delta_{\mathrm{C}} 75.1\left({ }^{3} J\right)$ further supported the structure of fragment $\mathbf{1}$. The structure of fragment $\mathbf{2}$ was derived from COSY cross peaks between the geminal protons at $\delta_{\mathrm{H}} 1.33$ and 1.53 , and $\delta_{\mathrm{H}} 1.33$ and $\delta_{\mathrm{H}} 3.79$ together with HMBC cross peaks between $\delta_{\mathrm{H}} 1.33$ and $\delta_{\mathrm{C}} 24.7\left({ }^{3} J\right)$ and $\delta_{\mathrm{C}} 71.6\left({ }^{2} J\right)$.

A symmetrical fragment 3 was postulated to account for the similar chemical shifts of the doubly bound carbon atoms, the allylic and the aliphatic carbon atoms. The HMBC spectrum established the bonds between carbon atoms at $\delta_{\mathrm{C}}$ 13.3 and $\delta_{\mathrm{C}} 22.2\left({ }^{2} J \delta_{\mathrm{C}} 22.2, \delta_{\mathrm{H}} 0.60\right) ; \delta_{\mathrm{C}} 22.2$ and $\delta_{\mathrm{C}} 31.5\left({ }^{3} J \delta_{\mathrm{C}} 31.5, \delta_{\mathrm{H}} 0.60\right)$. The assignments of all the other carbon atoms with similar chemical shifts in the fragment were interchangeable.
Infrared spectrum peaks at $1623(\mathrm{C}=\mathrm{C}$ str., lit. value $\left.1665-1635 \mathrm{~cm}^{-1}\right)$ and $723.0 \mathrm{~cm}^{-1}(=\mathrm{CH}$ oop., lit. value $725-675 \mathrm{~cm}^{-1}$ ) were indicative of a cis configuration.

The long-range correlations (Fig. 1) between $\delta_{\mathrm{C}}$ 51.2 and $\delta_{\mathrm{H}} 1.33\left({ }^{3} J\right), \delta_{\mathrm{C}} 71.6$ and $\delta_{\mathrm{H}} 3.29\left({ }^{3} J\right), \delta_{\mathrm{C}}$ 175.5 and $\delta_{\mathrm{H}} 3.79\left({ }^{3} J\right), \delta_{\mathrm{C}} 175.5$ and $\delta_{\mathrm{H}} 1.01$ cluster $\left({ }^{2} J\right)$, and $\delta_{\mathrm{C}} 29$ cluster and $\delta_{\mathrm{H}} 1.17\left({ }^{2} J\right)$ gave the structure of menthalactone (Fig. 2). This structure would also explain the multiplicities of the pro-

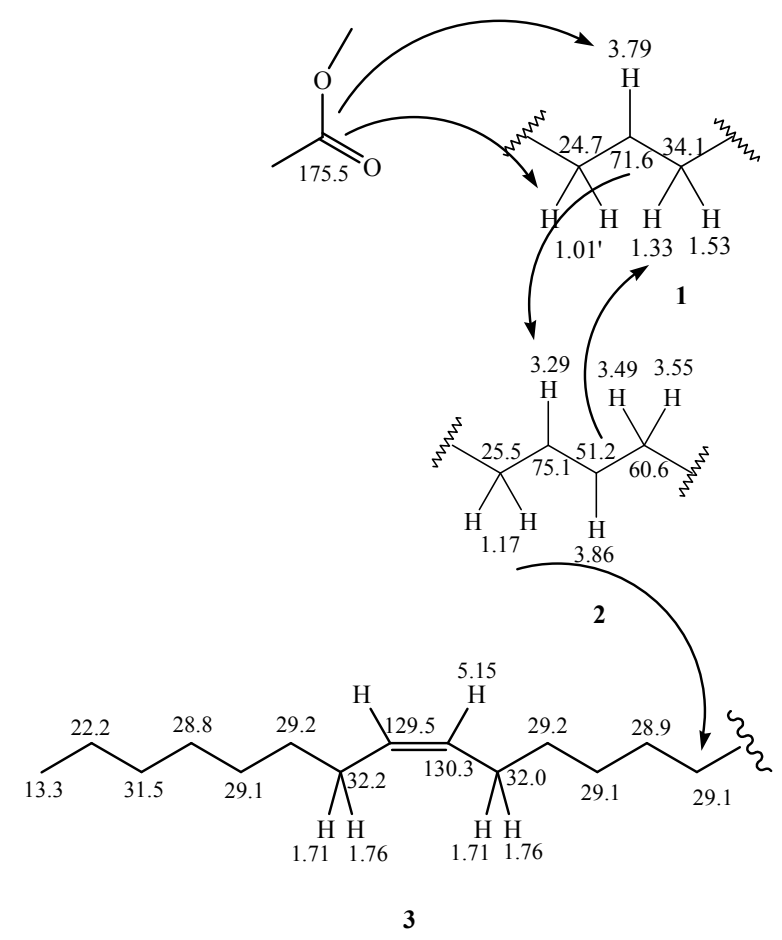

Fig. 1. Long-range correlations among fragments $\mathbf{1}, \mathbf{2}$ and 3. 


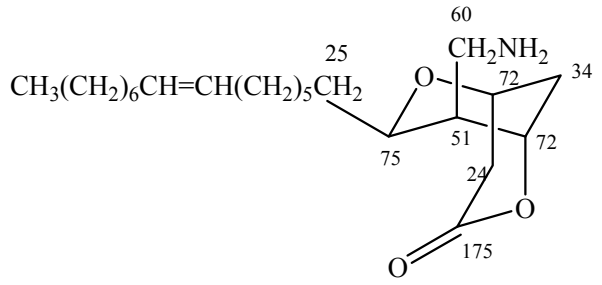

Fig. 2. Chemical structure of menthalactone.

tons at $\delta_{\mathrm{H}} 1.33$ and $\delta_{\mathrm{H}} 1.53$ attached to the carbon atom corresponding to $\delta_{\mathrm{C}} 34.0$. The bulky longchain alkene moiety 3 would normally occupy an equatorial position and the proton corresponding to $\delta_{\mathrm{H}} 3.29$ would therefore be axial. With a $J$ value of $4 \mathrm{~Hz}$ between $\delta_{\mathrm{H}} 3.29$ and $\delta_{\mathrm{H}} 3.86$, the proton at $\delta_{\mathrm{H}} 3.86$ would be equatorial and hence, the $-\mathrm{CH}_{2} \mathrm{NH}_{2}$ moiety is axial.

Pharmacological studies (Villaseñor et al., 1995) indicated that the hexane extract of $M$. cordifolia exhibits a central nervous system-depressant effect as evidenced by a decrease in motor activity and ataxia which would also account for its analgesic activity.

\section{Experimental}

\section{General}

${ }^{1} \mathrm{H}$ NMR (400 MHz), ${ }^{13} \mathrm{C}$ NMR $(100 \mathrm{MHz})$ and 2D NMR studies were conducted in $30 \% \mathrm{CD}_{3} \mathrm{OH} /$ $\mathrm{CDCl}_{3}$ with TMS as internal standard. Normal phase liquid chromatography (NPVLC) and TLC were done on silica gel using gradient ratios of hexane, EtOAc/hexane, and EtOH/EtOAc. Detection included $\mathrm{I}_{2}$, vanillin- $\mathrm{H}_{2} \mathrm{SO}_{4}$ spray followed by heating, and UV light. All bioassay data are presented as mean \pm standard deviation (S.D.) and were analyzed statistically using Kruskal Wallis one-way analysis of variance by ranks (Walpole, 1997).

\section{Extraction and isolation}

M. cordifolia leaves were purchased from the National Research Council of the Philippines (NRCP) in Bicutan, Taguig, MM. Approx. $10 \mathrm{~kg}$ of leaves were air-dried and then homogenized in ethanol. The ethanol extract was filtered and then concentrated in vacuo. The ethanolic fraction was partitioned between hexane and water. The aqueous layer was further extracted with $\mathrm{CHCl}_{3}(6 \times)$ and then with EtOAc (6×). The hexane, $\mathrm{CHCl}_{3}$, and EtOAc portions were concentrated in vacuo to give fractions $\mathrm{FB}, \mathrm{FC}$, and $\mathrm{FD}$, respectively.

Approx. $10 \mathrm{~g}$ of the FB fraction were subjected to NPVLC and eluted with hexane, $10 \%$ gradient ratios of EtOAc in hexane, EtOAc, $10 \%$ gradient ratios of $\mathrm{EtOH}$ in EtOAc. The column fractions were combined according to analytical TLC results into 10 fractions, FB1 to FB10.

NPVLC of fraction FB6 (2.7527 g) with 4\% gradient ratios of EtOAc in hexane (40\% to $80 \%)$, 90\% EtOAc in hexane, EtOAc, 50\% EtOH in EtOAc, and EtOH resulted in 7 fractions, FB6A to FB6G. Fraction FB6F was repeatedly subjected to NPVLC using $4 \%$ gradient ratios of $40 \%$ to $80 \%$ EtOAc in hexane to afford a white crystalline solid labeled as FB6Fc and later renamed as menthalactone.

Menthalactone: White crystals; m.p. (uncorr) $135.1^{\circ} \mathrm{C}$ (with decomposition). - FTIR (KBr): $v=$ 3332 and $3221\left(-\mathrm{NH}_{2}\right), 2920,2851,1756(\mathrm{C}=\mathrm{O})$, 1623 (C=C), 1543 (N-H bend), 1468, 1362, 1278 (C-N str.), 1121 (C-O str.), 871, $723 \mathrm{~cm}^{-1} \cdot-{ }^{13} \mathrm{C}$ NMR $\left(100 \mathrm{MHz}, 30 \% \mathrm{CD}_{3} \mathrm{OH} / \mathrm{CDCl}_{3}\right)(\mathrm{DEPT})$ [C-H HETCORR]: $\delta=13.3\left(-\mathrm{CH}_{3}\right)$ [0.60], 22.2 $\left(-\mathrm{CH}_{2}\right)$ [1.01], $24.7\left(-\mathrm{CH}_{2}\right)\left[1.01\right.$ ', 1.17], $25.5\left(-\mathrm{CH}_{2}\right)$ [1.01', 1.17], $28.8\left(-\mathrm{CH}_{2}\right)$ [1.01], $28.9\left(-\mathrm{CH}_{2}\right)$ [1.01], $29.06\left(-\mathrm{CH}_{2}\right)$ [1.01], $29.10\left(-\mathrm{CH}_{2}\right)$ [1.01], 29.14 $\left(-\mathrm{CH}_{2}\right)$ [1.01], $29.16\left(-\mathrm{CH}_{2}\right)$ [1.01], $29.20\left(-\mathrm{CH}_{2}\right)$ [1.01], $31.5\left(-\mathrm{CH}_{2}\right)$ [1.01], $32.0\left(-\mathrm{CH}_{2}\right)$ [1.71, 1.76], $32.2\left(-\mathrm{CH}_{2}\right)[1.71,1.76], 34.0\left(-\mathrm{CH}_{2}\right)[1.34,1.53]$, $51.2(-\mathrm{CH})$ [3.86], $60.6\left(-\mathrm{CH}_{2}\right)$ [3.52], $71.6(-\mathrm{CH})$ [3.79], $71.8(-\mathrm{CH}), 75.1(-\mathrm{CH})$ [3.29], $129.5(=\mathrm{CH})$ [5.15], $130.3(=\mathrm{CH}), 175.5 .-{ }^{1} \mathrm{H}$ NMR $(400 \mathrm{MHz}$, $30 \% \mathrm{CD}_{3} \mathrm{OH} / \mathrm{CDCl}_{3}$ ) [COSY] $\{\mathrm{HMBC}\}: \delta=0.60$ $(3 \mathrm{H}, \mathrm{t}, J=6.7 \mathrm{~Hz})[1.01]\left\{22.2\left({ }^{2} J\right), 31.5\left({ }^{3} J\right)\right\}, 1.01$ (br s) $[0.60,1.71]$ and 1.01 ' [3.79, 1.17], $1.17(\mathrm{~d}$, $J=7.1 \mathrm{~Hz})$ [1.01'] $\left\{29\right.$ cluster, $\left.51.2\left({ }^{3} J\right)\right\}, 1.33(\mathrm{~m})$ [1.53] $\left\{24.7\left({ }^{3} J\right), 51.2,71.5\left({ }^{2} J\right)\right\}, 1.53(\mathrm{~m})$ [1.34], $1.71[1.01,5.15]\left\{29\right.$ cluster, $\left.129.5\left({ }^{2} J\right), 130.3\left({ }^{2} J\right)\right\}$, 1.76 [ 1.71], $3.29(1 \mathrm{H}, \mathrm{d}, J=4.36 \mathrm{~Hz})[3.86,1.17]$ $\{71.5\}, 3.49(1 \mathrm{H}, \mathrm{dd}, J=11.5 \mathrm{~Hz}$ and $4 \mathrm{~Hz})[3.55$, $3.86]\left\{51.2\left({ }^{2} J\right), 75.1\left({ }^{3} J\right)\right\}, 3.55(1 \mathrm{H}, \mathrm{dd}, J=11.5 \mathrm{~Hz}$ and $4 \mathrm{~Hz})[3.49,3.86]\left\{51.2\left({ }^{2} J\right), 75.1\left({ }^{3} J\right)\right\}, 3.79$ $(\mathrm{dd}, J=8 \mathrm{~Hz}$ and $3.6 \mathrm{~Hz})\left[1.34,1.01^{\prime}\right]\left\{34.1\left({ }^{2} J\right)\right.$, $175.5\}, 3.86(1 \mathrm{H}, \mathrm{q}, J=4 \mathrm{~Hz})[3.55,3.29], 5.15(1 \mathrm{H}$, br s) $[1.71]\left\{31.99,129.5\left({ }^{2} J\right)\right\}$. 


\section{Analgesic bioassay: Acetic acid-induced writhing test}

Swiss Webster albino mice, weighing 20-25 g, were used as test animals. Five mice were used per test sample. Approx. 30 min after oral administration of the test solutions, $0.7 \%$ acetic acid was injected intraperitoneally $(0.01 \mathrm{ml} / \mathrm{g}$ mouse $)$. The number of squirms for each mouse was then

Maramba N. P., Dayrit F. M., de Castro N. F., Estrada H. R., Sylianco C. Y. L., Lingao A. L., Quijano R. F., and Quintana E. G. (1991), Selection and Scientific Validation of Medicinal Plants for Primary Health Care. DOST Technical Report Series No. 12, Philippine Council for Health Research and Development, Department of Science and Technology, Bicutan, Taguig, Metro Manila, p. 42.

Maramba N. P., Saludez J. D., Sia I. C., Alegre O. Y., de Asis G. A., Bagnaes L. B., Macalagay R. U., and Bajao A. R. (1993), Guidebook on the Proper Use of Medicinal Plants. NSTA-UP Research Project No. 8003 Md. Katha Publishing Co., Inc., Quezon City, Philippines, p. 86.

Quisumbing E. (1978), Medicinal Plants of the Philippines. Katha Publishing Co., Inc., Quezon City, Philippines, pp. $822-824$. counted for $15 \mathrm{~min}$ beginning from $5 \mathrm{~min}$ after acetic acid injection (Villaseñor et al., 2002).

\section{Acknowledgement}

The authors thank the Office of Research Coordination of the University of the Philippines, Diliman for funding.

Tan M. L. (1978), Philippine Medicinal Plants in Common Use. Their Phytochemistry and Pharmacology. Luzon Secretariat of Social Action, Quezon City, Philippines, p. 29.

Villaseñor I. M., Catalon L., Chua C., Edu D., and Nakar J. (1995), Preliminary bioactivity studies on Mentha cordifolia Opiz. leaf extracts. Phil. J. Sci. 124, $333-343$.

Villaseñor I. M., Angelada J., Canlas A. P., and Echegoyen D. (2002), Bioactivity studies on $\beta$-sitosterol and its glucoside. Phytother. Res. 16, 417-421.

Walpole R. E. (1997), Introduction to Statistics. Prentice Hall Intl., Inc., Singapore, pp. 450-455. 